\title{
Possible Uses of Lactic acid Bacteria for Food and Feed Production
}

\author{
Elena Bartkiene $^{1 *}$, Vita Krungleviciute ${ }^{1}$ and Vadims Bartkevics ${ }^{2}$ \\ ${ }^{1}$ Lithuanian University of Health Sciences, Lithuania \\ ${ }^{2}$ Institute of Food Safety, Latvia
}

Submission: February 23, 2017; Published: March 03, 2017

"Corresponding author: Elena Bartkiene, Lithuanian University of Health Sciences, Tilzes g 18, 47181 Kaunas, Lithuania, Tel: +37060135837; Fax: +37037300152; Email: elena.bartkiene@lsmuni.lt

\section{Introduction}

Lactic acid bacteria (LAB) are generally fastidious on artificiall media, but they grow readily in most food substrates and lower the $\mathrm{pH}$ rapidly to a point where competing organisms are no longer able to grow. Spontaneous fermentation of food/feed may differ from each other in terms of environmental microbiota and fermentable substrate. Spontaneous fermentation may fail, because it is not possible to ensure the same quality of the end product. However, spontaneously fermented products represent a source of $\mathrm{LAB}$ with potential interesting functional and technological properties, and the choice of the starter cultures has a critical impact on the palatability, processability, nutritional attributes, sustainability, and safety of food and feed.

\section{Lactic acid bacteria for bread production}

Sourdough fermentation is the most natural and bestperforming process to ensure optimal sensory and functional characteristics of bread, also, it should be noted, that the selection of LAB, having peculiar characteristics, can reduce the mould growth [1] and acrylamide formation in bread [25]. The acrylamide content in mixed rye - wheat bread could be lowered by using LAB with lower amylolytic activity [3]. Thus, the significant effect of LAB protease activity on the fermentation process as well as on acrylamide formation in bread can be related. A. niger glucoamylase in conjunction with an appropriate LAB strain could be used as one of the factors regulating acidification in dough, herewith decreasing the acrylamide content in bread.

Different tendencies were found in bread produced with Helianthus tuberosus L. (JA) tubers, which is a good source of prebiotic inulin [4]. The proteolytic activity of LAB does not correlate with acrylamide content in wheat bread made with JA additives $(\mathrm{R}=0.3683 ; \mathrm{p}=0.2015)$, but there was a strong correlation between acrylamide and the sourdough $\mathrm{pH}(\mathrm{R}=$
0.8801; $P=0.0056)$, and with LAB amylase activity excreted in JA material $(\mathrm{R}=0.9719 ; \mathrm{P}=0.003)$.

Also, a number of fermented products utilize cereals in combination with legumes, thus improving the overall protein quality of the fermented product. Cereals are deficient in lysine, but are rich in cystine and methionine, legumes on the other hand are rich in lysine but deficient in sulphur-containing amino acids [6-8]. Hereby, by combining cereals with legumes, the overall protein quality of bread could be improved. Fermentation of lupine by pure LAB significantly improved the nutritive value of lupine eliminating the trypsin inhibitors (reduction of $21.8 \%$ ) and increasing the soluble protein content up to $18.9 \%$ thus improving protein digestibility by $17.1 \%$ [5].

\section{Lactic acid bacteria for tomatoes nutritional value increasing}

Processing of tomatoes with selected LAB strains resulted in several important changes in carotenoid concentration and lycopene isomer profile. Treatment with LAB breaks down the tomato cell matrix and makes the carotenoids more available, which resulted in higher level of total carotenoids. Moreover, lactic acid fermentation of tomato resulted in a large lycopene bioavailability accompanied by increased cis-lycopene content. According to our results, selected LABmay be useful for preservation of tomatoes, which could be recommended as a way of obtaining more biologically accessible products with functional value [9].

\section{Lactic acid bacteria for meat products value and safety increasing}

The nutritional strategies to improve the quality of food products of animal origin are relatively newapproach. Acoording to our results, fermented with selected LAB tomato powder can be recommended as both a colouring agent and a source of 
lycopenein the preparation of ready-to-cook minced pork meat [10]. Satureja montana L. plants fermented with BLIS producing $\mathrm{LAB}$ could be a good alternative for ready-to-cook minced porkprocessing to prevent meat decolouration and microbial spoilage, thus increasing acceptability and shelf-life of meat products [11]. Also, our study showed the potential to use the potato tuber juice as a natural substrate for LAB fermentation and natural marinades for meat treatment production. The cheap natural marinades,based on potato juice fermented with selected LAB,could be recommended for pork meat treatment to improve its tenderness and color, thus increasing the overall acceptability [12]. Furthermore, the influence of surface treatment selected LAB, previously cultivated in an potato juice, on the formation of polycyclic aromatic hydrocarbons (PAHs) and biogenic amines (BAs) incold smoked pork meat sausages was investigated. Moreover, sausages treatment with LAB after the smoking on PAHs content changes was evaluated. Additionally, the inhibitory effects of LAB metabolites on food spoilage bacteria was determined [13]. The results confirm that potato juice could be used as an alternative substrate for LAB cultivation, and the obtained fermented bioproducts could be applied for surface treatment of cold smoked pork sausages in case to reduce microbial contamination, and PAHs content in final product.

\section{Lactic acid bacteria for higher value feed production}

The $50 \mathrm{ml}$ of with selected $\mathrm{LAB}$ fermented potato juice contain $\neg$ ing $9.6 \log 10 \mathrm{CFU} / \mathrm{ml}$ of LAB per day, administered for 14days, reduced the risk of developing acidosis (it stabilised blood $\mathrm{pH} ; \mathrm{P}<0.05)$, reduced lactate and $\mathrm{PCO} 2$ concentrations $(\mathrm{P}<0.05)$, and the risk of liver lesions (reduced AST concentration; $\mathrm{P}<0.005$ ) in blood and $\mathrm{E}$. coli in the faeces of calves [14].

As well as the isolated Pediococcus acidilactici BaltBio01 and Pediococcus pentosaceus BaltBio02 strains were cultivated in barley and wheat bran $(90 / 10, \mathrm{~m} / \mathrm{m})$ substrate, and the developed fermented feed stock, with high content of valuable Pediococcus, was used for Lithuanian black and white dairy cattle feeding [15]. In addition, the influence of fermented feed stock on milk production and composition was determined. Isolated strains demonstrated versatile carbohydrate metabolism, grown at $30{ }^{\circ} \mathrm{C}$ and $37{ }^{\circ} \mathrm{C}$ temperatures, acidic tolerance, showed to be non resistant to antibiotics and have antimicrobial activity. Cereal by-products (barley and wheat bran) bioconversion using isolated microorganisms allows to produce safer (reduced Enterobacteria, aerobic bacteria, yeast and fungi count) fermented feed stock with high content of Pediococcus. At the beginning of the feeding experiment, no significant differences in feed intake, milk production and milk composition were established between the test groups. Control and trial groups received the same ration; however, the trial groups also received $200 \mathrm{~g}$ per cow of the fermented feed stock containing $9.6 \log 10$ CFU g-1 Pediococcus daily for 66 days (group B, received 200g fermented with P. acidilactici/cow/day feed stock, group C received 200g fermented with P. pentosaceus/cow/day feed stock, and group D received $200 \mathrm{~g}$ fermented with P. acidilactici and P. pentosaceus/cow/day feed stock). After 33 days of experiment, significant milk yield increase in group D (yield $34.64 \pm 3.56 \mathrm{~kg} \mathrm{~d}-1$ ), compared with group A (yield $29.93 \pm 3.55 \mathrm{~kg}$ $\mathrm{d}-1$ ) and group C (yield $30.24 \pm 3.99 \mathrm{~kg} \mathrm{~d}-1$ ) was established. After 66 days of feeding, similar trends were found, i.e. milk yield significantly increased in group D (yield $35.04 \pm 3.04 \mathrm{~kg} \mathrm{~d}-1$ ) compared with group A (yield 29.04 $\pm 3.88 \mathrm{~kg} \mathrm{~d}-1$ ).

It can be inferred that barley and wheat bran could be used to promote growth of P. acidilactici BaltBio01 and P. pentosaceus BaltBio02, and produced fermented feed stock could be recommended for dairy cattle feeding in order to increase milk production [16-18].

\section{Conclusion}

The value of fermented food/feed play a vital role in diet and nutrition. The benefits which are associated with fermentation are increased shelf life and sustainability, palatability, and nutritional value. Application of lactic acid bacteria for the food/ feed biotechnology industry look promising and warrant further research.

\section{References}

1. Dalia C, Grazina J, Algimantas P, Elena B (2013) Antimicrobial activity of lactic acid bacteria against pathogenic and spoilage microorganism isolated from food and their control in wheat bread. Food control 31(2): 539-545.

2. Elena B, Vadims B, Iveta P, Vita K, Sigrid M, et al. (2017) The Contribution of P. acidilactici, L. plantarum, and L. curvatus starters and L-(+)-lactic acid to the acrylamide content and quality parameters of mixed rye Wheat bread. LWT-Food science and technology.

3. Elena B, Idan J, Grazina J, Daiva V, Iveta P, et al. (2013) Study on the reduction of acrylamide in mixed rye bread by fermentation with bacteriocin-like inhibitory substances producing lactic acid bacteria in combination with Aspergillus niger glucoamylase. Food control 30(1): 35-40.

4. Elena B, Ida J, Grazina J, Daiva V, Iveta P, et al. (2013) Effect of fermented Helianthus tuberosus L. tubers on acrylamide formation and quality properties of wheat bread. LWT - Food Science and Technology 54(2): 414-420.

5. Elena B, Ida J, Grazina J, Daiva V, Iveta P, et al. (2013) Effect of lactic acid fermentation of lupine wholemeal on acrylamide content and quality characteristics of wheat-lupine bread. Int J Food Sci Nutr 64(7): 890896.

6. Vytaute S, Elena B, Vadims B, Janis R, Daiva Z, et al. (2016) Amino acids profile and antioxidant activity of different Lupinus angustifolius seeds after solid state and submerged fermentations. J food sci technol 53(12): 4141-4148.

7. Elena B, Vadims B, Janis R, Vytaute S, Daiva Z, et al. (2016) Changes in the free amino acids and the biogenic amine contents during lactic acid fermentation of different lupin species. International journal of food science \& technology 51(9): 2049-2056.

8. Elena B, Vadims B, Janis R, Vytaute S, Egle-Aida, et al. (2016) The Effect of Pediococcus acidilactici and Lactobacillus sakei on biogenic amines formation and free amino acid profile in different lupin during fermentation. LWT-Food science and technology 74: 40-47. 
9. Elena B, Daiva V, Grazina J, Pranas V, Dalia U (2013) Lactic acid fermentation of tomato: effects on cis/trans lycopene isomer ratio, b-carotene mass fraction and formation of L(+)- and D(-)-lactic acid. Food technology and biotechnology 51(4): 471-478.

10. Elena B, Grazina J, Daiva Z, Pranas V, Dalia U (2015) The Use of tomato powder fermented with pediococcus pentosaceus and lactobacillus sakei for the ready-to-cook minced meat quality improvement. Food Technol Biotechnol 53(2): 163-170.

11. Elena B, Erika M, Grazina J, Daiva Z, Audrius M, et al. (2015) Pork meat products functional value and safety parameters improving by using lactic acid fermentation of savory plants. Journal of food science and technology 52(11): 7143-7152.

12. Erika M, Elena B, Vita K, Daivab Z, Grazina J, et al. (2016) Effect of natural marinade based on lactic acid bacteria on pork meat quality parameters and biogenic amine contents. LWT- Food science and technology 69: 319-326.

13. Elena B, Vadims B, Erika M, Vita K, Aleksandr N, et al. (2017) The Impact of lactic acid bacteria with antimicrobial properties on biodegradation of polycyclic aromatic hydrocarbons and biogenic amines in cold smoked pork sausages. Food control 71: 285-292.

14. Elena B, Vita K, Ramunas A, Jone K, Audrius K, et al. (2016) Antimicrobial activity of lactic acid bacteria multiplied in an alternative substrate and their influence on physiological parameters of new-born calves. Veterinární medicína 61(12): 653-662.

15. Vita K, Rasa Z, Ingrida M, Jone K, Rolandas S, et al. (2017) Applicability of Pediococcus strains for fermentation of cereal bran and its influence on the milk yield of dairy cattle. Zemdirbyste = Agriculture 104(1): 6370 .

16. Elena B, Grazina J, Ramunas G (2016) Fermented feed of plant origin = Aliment fermenté d'origine végétale. p. 03.

17. Elena B, Grazina J, Ramunas G (2016) Probiotic fermented feed additives $=$ Additifs alimentaires fermentés probiotiques. p. 02.

18. Elena B, Vita K, Grazina J, Daiva J, Zita M (2015) Solid state fermentation with lactic acid bacteria to improve the nutritional quality of lupin and soya bean. J Sci Food Agric 95(6): 1336-1342.

\section{Your next submission with Juniper Publishers will reach you the below assets}

- Quality Editorial service

- Swift Peer Review

- Reprints availability

- E-prints Service

- Manuscript Podcast for convenient understanding

- Global attainment for your research

- Manuscript accessibility in different formats

( Pdf, E-pub, Full Text, Audio)

- Unceasing customer service

Track the below URL for one-step submission https://juniperpublishers.com/online-submission.php 